\title{
The nature and the scope of the global economic crisis' impact on employment trends and policies in South East Europe
}

\author{
Qerim Qerimi \\ Law \& Development Research Group, University of Antwerp \\ Belgium; \\ Faculty of Law, University of Prishtina \\ Kosovo \\ Qerim.Qerimi@uantwerpen.be \\ Bruno S. Sergi \\ Davis Center for Russian and Eurasian Studies, Harvard University \\ USA; \\ Department of Economics, University of Messina \\ Italy \\ bsergi@fas.harvard.edu
}

Abstract. This paper investigates the impact of the global economic downturn, its nature and impacts on the state of employment in the region of South East Europe. As the financial crisis spilled over into the real sector, its effects, with varying magnitude, ranging from relatively consequential to devastating, were such that inescapably impacted lives across the planet, with the poorest as the most vulnerable and marginalized bearing a particularly heavy burden. The crisis has had disproportionate impacts on social and economic rights and well-being of specific groups of people, in particular, women and children, migrants and minorities. Limited to the context of South East Europe, this paper's main thrust is to explore what impact the global financial crisis has exerted on the employment and poverty trends across the region. It thus seeks to delineate the extent to which unemployment and, where applicable, poverty trends have been affected by the crisis. Nevertheless, participation and employment rates can differ, as they do in many of these countries in question, according to gender, level of education, age or urban/rural origin. The crisis' ensuing social gap and its scope shall be particularly observed. The referenced data mainly originate from such authoritative agencies as the World Bank, IMF, ILO as well as national bureaus of statistics.

Keywords: global economic downturn, labour markets, unemployment, social welfare, Eurozone crisis, South East Europe, Balkans.

JEL Classification: G15, J6, J64, J4, H1, K42 


\section{INTRODUCTION}

The most recent history of the South East Europe, often more narrowly defined as the Balkans, has shown signs of the overall appreciable political stability. Albeit in some places fragile, the political landscape of this peninsula is nonetheless more peaceful than perhaps during any other period since the 1990s conflicts in the Balkans. Involvement of the international community, together with the changes brought from the within, have shaped the socioeconomic climate in the region. The trajectory of progress may, however, not be taken for granted. The process of transformation is encountering difficulties. Indeed, social stability is a fundamental prerequisite to any meaningful development, and its absence can lead to tensions or instability.

Unemployment rates had been already high in the Balkans prior to the global economic crisis, though during its aftermath they rose by $2 \%$ more. In the EU countries, this increase was about 2.4\% (Balaj, 2010: 41). There is still a clear difference from the rest of Europe since unemployment rates in this region are significantly higher than the EU-27 average (Galgóczi \& Sergi, 2012), while the region itself has not been as connected to the global markets as that of the EU. Globally, the number of people unemployed in the world increased by almost 34 million in the period between 2007 and 2009. According to the ILO estimates, the global unemployment rate in 2009-the year most hit by the effects of the crisis-was at 6.6 per cent.

Latest available data for 2016 show a global decrease in unemployment from the 2009 levels, albeit at a slower pace. Indeed, the unemployment rate for developed economies as a whole has been decreased as a result of improvements gained in the Northern, Southern and Western Europe region and the United States. This same trend has been, however, lacking in emerging economies, which were experiencing a slight increase, thus conditioning the rather modest results at a global scale (ILO, 2016). According to ILO's projections (2016: 12), emerging economies that will contribute the greatest number of unemployed are China ( 0.8 million) and Brazil (0.7 million).

Table 1

Number of the Unemployed and Unemployment Rates Globally

\begin{tabular}{lcccc}
\hline & \multicolumn{3}{c}{ Years } \\
& $\mathbf{2 0 0 7}$ & $\mathbf{2 0 0 8}$ & $\mathbf{2 0 0 9}$ & $\mathbf{2 0 1 6}$ \\
\hline Number of unemployed (Millions) & 177,7 & 184,9 & 211,5 & 199.4 \\
Unemployment Rates (as \%) & 5,7 & 5,8 & 6,6 & 5.8 \\
\hline
\end{tabular}

Source: ILO (2010 and 2016).

The findings of the report published by the Institute for Regional and International Studies (2010) forecasted a very difficult and slow process of job recovery, further continuing pressure on the state of welfare systems and public budgets. As the report puts its (p. 9), "sustained unemployment may cause social tensions and bring a rise in some crime forms and the grey economy". And as further noted by Freeman (2011), empirical evidence related to the post finance-induced recessions speak of workers as the greatest bearers of the cost of adjustment, be it through unemployment, depressed real wages or sluggish postrecession growth.

The relationship between the global and the local appears to be immense both in terms of the consequential downturn and its aftermath. It is worth recalling that one of the key traits of the latest economic crisis was a sudden collapse of credit systems on the global scale as banks stopped lending to each other in their fear of unknown consequences and uncertain exposure to toxic debts (Roubini \& Nihm, 2010). The effects soon reached the South-East Europe too, and their negative impact was more strongly felt in those countries where banks were internationally owned and the level of integration with global 
markets was higher. For instance, Turkey was only modestly affected because most of its banks are domestically owned.

Beyond the settings of the sudden collapse, the effects of the crisis were also experienced on other fronts. Due to the Eurozone crisis, remittances from migrants have been on the decrease. This poses another challenge to the social welfare systems of the South East European countries, in particular as the regional countries, some more than other, rely relatively heavily on remittances. Although the precise data on remittances may not be easily obtained and their accuracy is by their nature difficult to ascertain, Table 2 offers an important indication on the pertinent trends. Data for Kosovo and Montenegro are missing in the World Bank remittances database for 2008-2009. However, according to the IMF data, Kosovo's remittances as the share of GDP fell from $12.6 \%$ in 2007 to $11.9 \%$ in 2008, and then to $10.7 \%$ in 2009 . Data on Kosovo are available from the World Bank for 2016, which registers a clear increase from 10.7 in 2009 (IMF data) to 14.8 in 2016. The same 2016 World Bank data on Montenegro also show a comparably high level of $9.5 \%$, as well as an increase from the preceding years (8.00\% in 2010 and $8.8 \%$ in 2011). A clear increase is similarly registered in Croatia. In Bosnia and Herzegovina, there has been a notably modest improvement from 2009, with such trends being negative in cases of Albania, Macedonia and Serbia.

Table 2

Remittances in five Balkan countries

\begin{tabular}{ccccc}
\hline Country & $\begin{array}{c}\text { Remittances as the } \\
\text { share of GDP, 2008 } \\
\mathbf{( \% )}\end{array}$ & $\begin{array}{c}\text { \% decline in } \\
\text { remittances' flow in } \\
\text { 2008-2009 }\end{array}$ & $\begin{array}{c}\text { Remittances } \\
\text { as the share of } \\
\text { GDP, 2009 } \\
\mathbf{( \% )}\end{array}$ & $\begin{array}{c}\text { Remittances as } \\
\text { the share of GDP, } \\
\mathbf{2 0 1 6}(\mathbf{\%})\end{array}$ \\
\hline $\begin{array}{c}\text { Albania } \\
\text { Bosnia and }\end{array}$ & $12.2 \%$ & $0.0 \%$ & $12.2 \%$ & $8.8 \%$ \\
Herzegovina & $14.8 \%$ & $3.9 \%$ & $10.9 \%$ & $11.1 \%$ \\
Croatia & $2.3 \%$ & $1.9 \%$ & $0.4 \%$ & $4.3 \%$ \\
Macedonia & $4.3 \%$ & $1.3 \%$ & $3.0 \%$ & $2.7 \%$ \\
Serbia & $11.1 \%$ & $1.8 \%$ & $9.3 \%$ & $8.5 \%$ \\
\hline
\end{tabular}

Source: World Bank remittances database.

\section{THE STATE OF (UN)EMPLOYMENT}

Despite sustained economic growth and stability, labour markets have not shown any significant scale of improvement, with high unemployment rates in the region, especially starker when looking at Bosnia and Herzegovina, Kosovo, and Macedonia. Indeed, the effects of the global economic crisis are clearly involved in this equation. The following Table 3 presents the state of unemployment in the Western Balkan countries over the years immediately preceding and succeeding the global financial crisis (see also Table 4 for most recent Eurostat data).

A longer-term perspective is given in Figure 1. The negative effects of the global economic downturn are not difficult to distinguish. The impact is perhaps more apparent in the cases of Croatia, Serbia and Montenegro. We can see clearly that the highest levels may be encountered in Kosovo, Bosnia and Herzegovina and Macedonia.

For the purposes of the data in Figure 1, unemployment is defined as the percentage of the labour force that is without a job. 
Table 3

The Impact of the Global Economic Crisis on the State of Unemployment in the Balkans (\%),

$$
2007-2010
$$

\begin{tabular}{ccccc}
\hline Country & $\mathbf{2 0 0 7}$ & $\mathbf{2 0 0 8}$ & $\mathbf{2 0 0 9}$ & $\mathbf{2 0 1 0}$ \\
\hline Albania & 13.8 & 12.5 & 12.8 & 13.5 \\
Bosnia and & 43.2 & 45.5 & 40 & 43.1 \\
Herzegovina & & & & 17.6 \\
Croatia & 11.8 & 13.7 & 16.1 & 43 \\
Kosovo & 40 & $42-43$ & 45 & 31.7 \\
Macedonia & 34.9 & 33.5 & 32.2 & 19.2 \\
Montenegro & 14.7 & 17.5 & 20.3 & 19.2 \\
Serbia & 18.8 & 14 & 16.6 & \\
\hline
\end{tabular}

Sources: European Bank for Reconstruction and Development; World Bank; International Monetary Fund; CIA World Factbook.

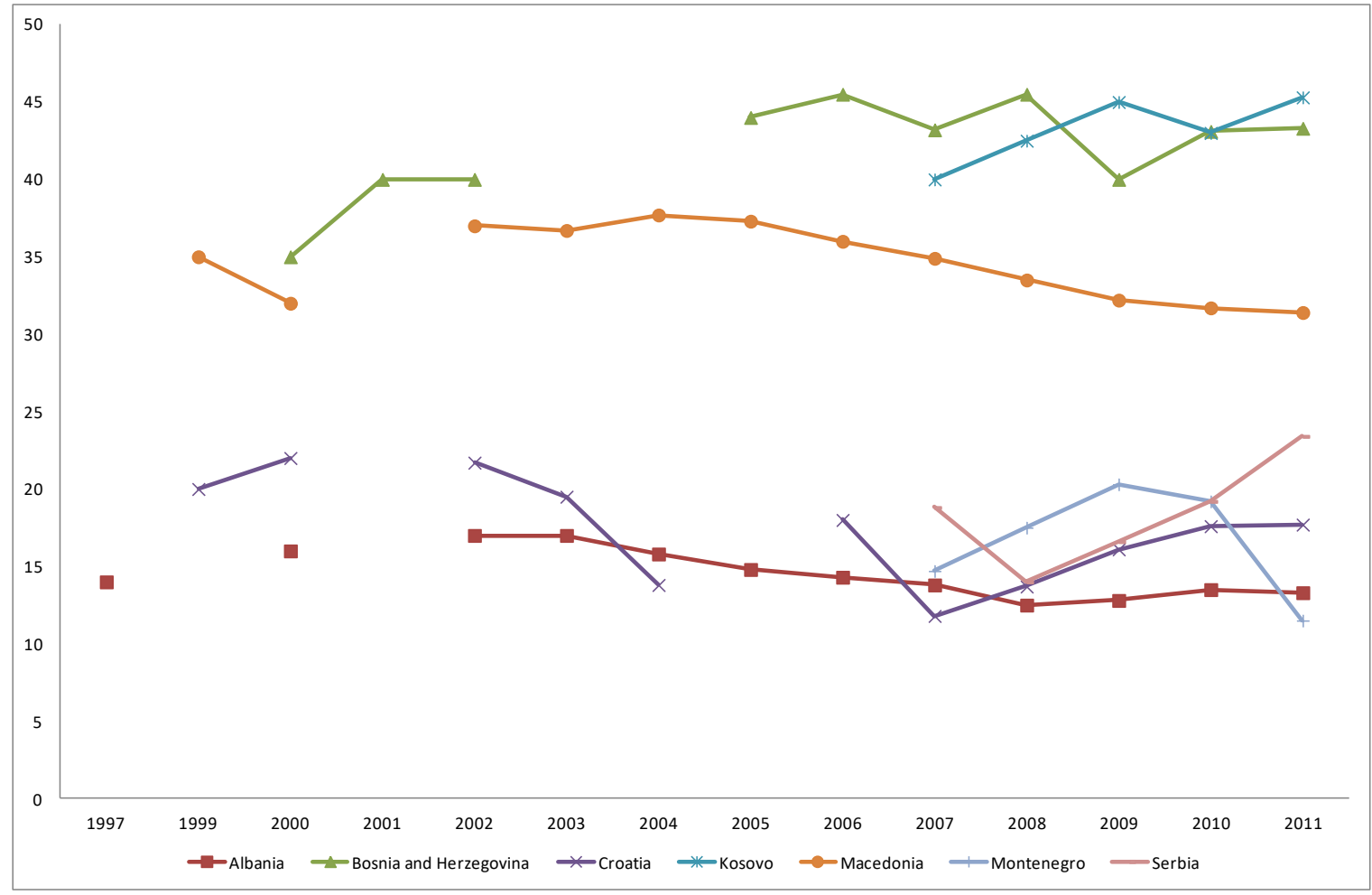

Figure 1. Unemployment rates in Balkan countries

Sources: International Monetary Fund; CLA World Factbook

It must be noted that, albeit insufficient, there is an overall positive trend, a relatively notable departure from the depressing unemployment state surrounding the period influenced most by the crisis. Table 4 below offers a comparative overview of the figures encompassing the period ranging from 2005 to 2015 : showing the statistical data for the years 2005, 2010 and 2015, respectively. This also provides an updated and more current account of the state of unemployment in the region.

Indeed, most recent Eurostat data for 2016 and 2017 are only available for EU member states, which include Croatia in this case. Eurostat data for 2017 on Croatia register the largest decrease in unemployment, 
i.e., $10.6 \%$ from $13.2 \%$ in the previous year, and $16.3 \%$ in 2015 (Eurostat, 2017); which-if sustained and/or constantly decreased-would join the club of such prime examples of recovery such as the United States who have come out of Wall Street's financial implosion and the Great Recession with some commendable degree of speed and success (see Freeman, 2012).

Table 4

Unemployment rates in the Balkans, 2005, 2010 and 2015 (\% of labour force: 15-74 years old)

\begin{tabular}{lccc}
\hline \multicolumn{1}{r}{ Country } & $\mathbf{2 0 0 5}$ & $\mathbf{2 0 1 0}$ & $\mathbf{2 0 1 5}$ \\
\hline Albania & 14.1 & 14.0 & 17.1 \\
Bosnia and Herzegovina & 43.9 & 27.3 & 27.9 \\
Croatia & 13.0 & 11.7 & 16.3 \\
Kosovo & 41.4 & 45.4 & 32.9 \\
Macedonia & 37.3 & 32.0 & 26.1 \\
Montenegro & 30.3 & 19.7 & 17.5 \\
Serbia & 20.8 & 19.2 & 17.6 \\
\hline
\end{tabular}

Source: Eurostat, Enlargement countries - labour market statistics (2016)

As data in this Table demonstrate, the effects of the global economic crisis are clearly involved in this equation. Richard Dobbs and Anu Madgavkar (2012), researchers at McKinsey, authored a survey on 'Why the jobs problem is not going away' and offered an analysis of the 'mismatch' between the demand for and supply of graduates that will expand even further by 2020. In the advanced economies, it could fail to respond as regards a total of 16 to 18 million graduates, i.e., a supply 11 per cent less than demand, with potentially damaging consequences for GDP growth. The mismatch between the demand for and supply of highly-qualified professionals is a major problem and overcoming it is essential for growth.

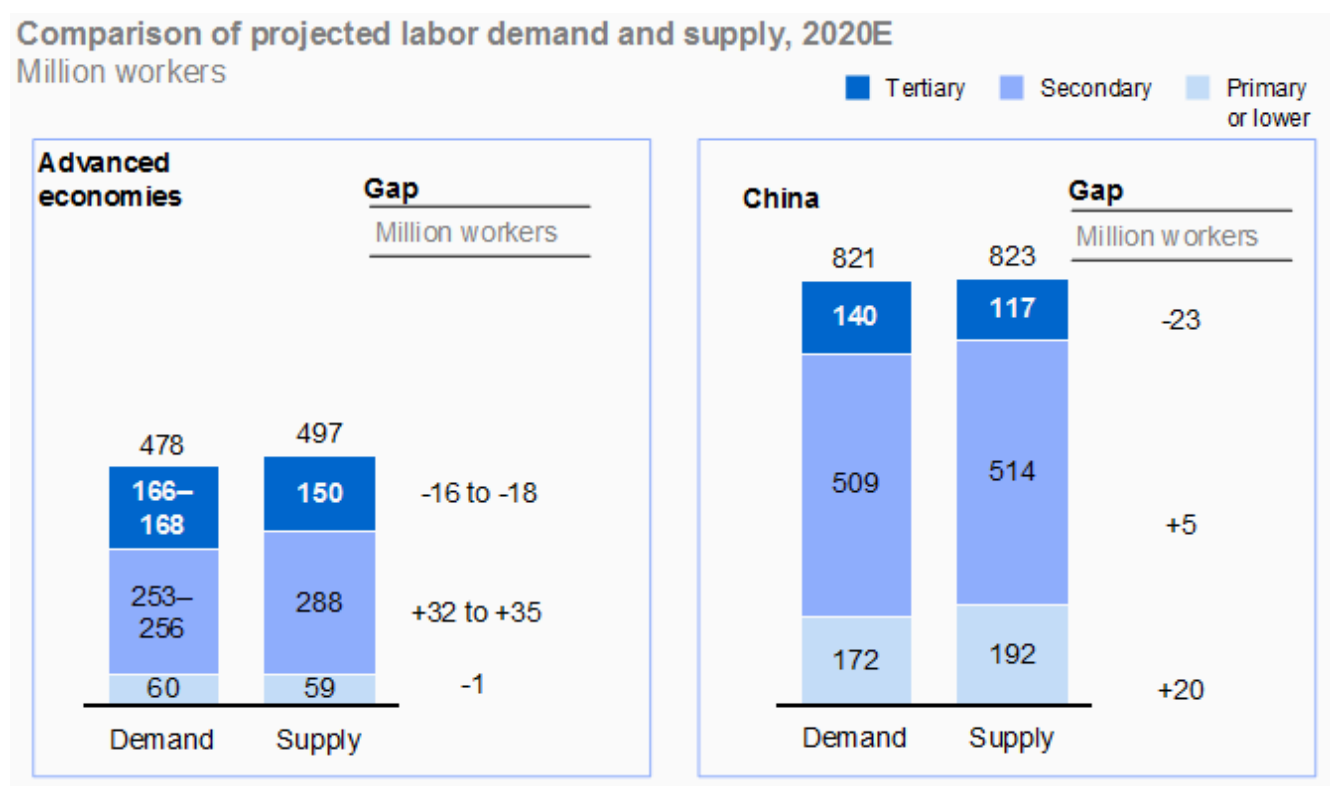

Figure 2. Projected labour demand and supply (advanced economies and China), 2020E

Notes: Gaps are \% of demand for shortages, and \% of supply for surpluses. Numbers may not sum due to rounding.

Sources: United Nations Population Division (2010 revision); ILAS A; ILO; Global Insight GDP consensus estimates; country sources for the US and France; China National Bureau of Statistics; McKinsey Global Institute analysis 
The competitiveness of the SEE region also relates to people's skills, quality, innovation and the existence of a national, as well as regional, system capable of enhancing these ideas. It is essential that young people-apparently the group most affected by the global economic crisis-be placed in conditions in which they can choose training in line with business and other market requirements. Not surprisingly, companies have increased their focus on the issue of the quality of human resources, focusing even more on excellence in regional and international competition. However, apart from in a few cases, the region has a very traditional model of development, with little technology, and background and trend where wellprepared graduates emigrate to find better job opportunities (Qerimi \& Sergi, 2013; EBRD, 2016-2017). Additionally, the sluggish economy, the slow pace of institutional development and political change form part of the broader equation that explains economic migration (EBRD, 2016-2017: 28).

If, on the other hand, we look at wage developments in the region, we can note signs of steady consolidation, not only in terms of the state of affairs in the immediate post-crisis period (2010), but also the longer trends, as observed by the latest, 2017 data. Wage dynamics—-for those who are in work-seem to be impressive (Table 5). Serbia and Montenegro, which also had a comparably more balanced labour market, take the lead, with real wage increases of 145 per cent (Serbia) and 95 per cent (Montenegro), respectively, in the subsequent aftermath of the global financial downturn. Among those South East European countries for which data were available, only Croatia, an actual EU member, had a lower real wage increase than the EU-27 average over the course of the decade, but Croatia also had an outstandingly high wage level for the region.

Table 5

Monthly remuneration per employee, 2010 and 2017

\begin{tabular}{ccccc}
\hline Country & $\begin{array}{c}\text { Euros } \\
\mathbf{( 2 0 1 0 )}\end{array}$ & \% (EU-27 = 100) & $\begin{array}{c}\text { Index of real wages, } \\
\mathbf{2 0 0 9}(\mathbf{2 0 0 0}=\mathbf{1 0 0})\end{array}$ & $\begin{array}{c}\text { Euros } \\
\mathbf{( 2 0 1 7 )}\end{array}$ \\
\hline Albania & 246 & 8.9 & $\mathrm{n} / \mathrm{a}$ & 419 \\
Bosnia and & 622 & 22.4 & $\mathrm{n} / \mathrm{a}$ & 675 \\
Herzegovina & 1054 & 38.0 & 121 & 1092 \\
Croatia & $\mathrm{n} / \mathrm{a}$ & $\mathrm{n} / \mathrm{a}$ & $\mathrm{n} / \mathrm{a}$ & 405 \\
Kosovo & 491 & 17.7 & 159 & 544 \\
Macedonia & 715 & 25.8 & 195 & 764 \\
Montenegro & 461 & 16.6 & 245 & 549 \\
Serbia & 2776 & 100 & 134 & $\mathrm{n} / \mathrm{a}$ \\
EU-27 & & &
\end{tabular}

Note: Data for South East Europe refer to average gross monthly wages.

Source: Vienna Institute for International Economic Studies (2011); National Bureaus of Statistics.

The Gini index measures the extent to which the distribution of income among individuals or households deviates from a perfectly equal distribution. A Gini index of zero represents perfect equalityeveryone has the same income-while an index of one (100 on the percentile scale) implies perfect inequality in the income distribution (one person has all the country's income; everyone else has nothing). Growing income inequality is a general trend in Europe and there is no evidence to support the assumption of an equality-efficiency trade-off. Depressing wages has led to a loss of efficiency, with the purchasing power of the population being maintained through credit that has eventually built to unsustainable trends and concluded in a debt crisis (Galgóczi \& Sergi, 2012). 


\section{GLOBAL FINANCIAL CRISIS AND SOCIAL DISPARITIES}

Up to this stage, the focus has been on the broader state of social welfare. The relevant state of affairs and trends were explored in light of the global economic crisis and the influence it exerted on the labour markets in the south-east European region and, to a certain extent, also globally. A more complete and comprehensive vision of this state of affairs would benefit significantly from an understanding of the effects produced on varying social categories. Certainly, participation in labour markets and employment rates differ significantly according to age, gender, level of education and other similar criteria. As argued by ILO (2010), it has indeed been the young who have been hit by the global financial crisis badly. This is, however, not to suggest that there was no problem at all with youth unemployment before the recession. It is quite the contrary. Although it remains true that youth unemployment numbers and rates were higher in 2009 as a result of the global crisis than at any other time since measurement began in 1991, yet the youth labour force participation has experienced constant struggle. For example, the youth male unemployment rate increased by 4.9 percentage points between 1998 and 2008. In 2009, a historical record of 75.8 million of unemployed youth was registered at the global level (ILO, 2011).

Statistics show a particularly dramatic increase in youth unemployment in the SEE region. The unemployment rate of those within 15 - 24 age group in Bosnia and Herzegovina reached 57.9 per cent in 2011 (Agency for Statistics of Bosnia and Herzegovina, 2011). In Montenegro, the unemployment rate for the same group was 40.4 per cent in Quarter 1 of 2012 (Montenegro Statistical Office, 2012). In the first quarter of 2012, Croatia registered 45.2 per cent unemployed from among those aged 15-24 (Croatian Bureau of Statistics, 2012). In Serbia, in April 2012, this percentage was as high as 50.9 (Statistical Office of the Republic of Serbia, 2012).

In contrast to the tough unemployment rates in the SEE countries observed above, in the Eurozone the youth unemployment among under-25s was 22.4 per cent. It must, however, be noted that in those EU member states that were most severely hit by the crisis, youth unemployment rates were similar or even higher than some of those in the Balkans region. For instance, in Greece and in Spain, youth unemployment reached 51.5 per cent and 52.7 per cent, respectively in June 2012. One could refer to the geographic location, climate and economic structure for an explanation of factors that contribute to the high rates of unemployment. More specifically, it is the economic structure and also industry that explain the level of integration into EU supply and production networks and the low level of intra-industry trade. The global economic crisis has also impacted other dimensions of labour, resulting in some countries with increased and higher unemployment rates for men than women. This effect is more prominently exposed in the case of Croatia, where the unemployment rate for men increased three times more than that for women. The same pattern, though to a different degree, was present among other regional countries. Thus, the unemployment rates of men were also significantly higher than those for women in Bosnia and Herzegovina, Bulgaria, Montenegro and Serbia. Romania would appear to be the only exception in the broader region, where the female unemployment rate has increased by more than the male unemployment rate (Bartlett \& Uvalić, 2013).

\section{GROWTH AND GOOD GOVERNANCE}

Another critical factor in the gamut of variables that could influence the state of social welfare are the broader economic variables. Indeed, as far as this aspect goes, as measured by the GDP growth, paths of appreciable economic growth could be found during the past decade everywhere across the SEE region.

Notwithstanding the relative increase in GDP, excluding the presumable temporary effects of the global economic downturn, the region suffers from a number of phenomena that prevent it from growing 
into a strong and stable economic arena, hence one that is conducive to a flourishing environment for stable cross-cultural interaction.

One of the region's persisting challenges is strengthening of the rule of law, in particular the institutions that are empowered to enforce laws (Qerimi \& Sergi, 2009; Sergi \& Qerimi, 2006, 2007 \& 2008). The problem of corruption has been one of the most enduring dilemmas confronting governments throughout history and it remains one of the most serious problems in the Balkans nowadays, along with organized crime. These high values of corruptive behaviour testify to the difficult path of reforming the institutional structure and strengthening the rule of law. It has been widely noted that economic activity in the region is often associated with, among other things, smuggling, extortion and tax evasion (Meyer \& Nash, 2002). Such factors have a considerable impact on the region's governments in their efforts to develop and stabilize their economies and collect revenue. This is certainly a major obstacle to attracting foreign investment. Establishing the rule of law is therefore of paramount importance. The notion of the rule of law should be reflective of its key elements. It should particularly involve the indispensable notions of any institutional reform process, namely independence and impartiality, accountability, representativeness, openness or transparency, oversight, gender sensitivity, and access to justice (Ndulo \& Duthie, 2009). Surely, interests are better served by open and transparent competition.

The major thrust of the South East European governments' effort will have to address the problem of corruption and the ineffective rule of law, as a matter of policy and as a part of their broader programs on governance and capacity building. There are some priority areas for the governments to concentrate broader efforts upon. These include policy dialogue directed toward economic liberalization and public administration reform, the liberalization of licensing regimes, the opening up of access to foreign exchange markets, the reduction of administered prices, the removal of subsidies and soft loans to favoured companies, and the introduction of a clear distinction between production and regulatory functions. These are all policy changes that can level the playing field and reduce opportunities for corrupt or illicit behaviour.

\section{THE DEMAND FOR REFORM: ALTERNATIVE AVENUES}

Some analyses may support the view that what has been taking place in terms of enterprise reforms in the region can be regarded as a process of rationalisation. The EBRD (2002) scored achievements in terms of enterprise reforms, market and trade reforms, and financial institution and infrastructural reforms. All the countries in the region have done well in terms of reforms of small-scale privatisation, trade and the monetary system, as well as with regard to price liberalisation (scores between 3 and $4+$ ). However, with regard to banking reforms, the EBRD reports either little progress or no progress at all (that is, between 1 and 2+, with a few scores of 3-). The EBRD's latest analysis (2016-2017) suggested that further reforms are necessary, noting in particular unequal access in financial systems (where the poor and less educated and the young people are disproportionately excluded from the financial system), and large gaps with regard to business skills and standards for financing and development of SMEs. The EBRD analysis also mentions the refugee crisis and economic migration from the Balkans region.

The main aspects in need of evaluation are social stability, EU membership, how to attract more capital and the future of industry. These are not separate issues and depend on the credibility of the entire Peninsula as a potential new focal point for entrepreneurs. These countries must exhibit further progress in reform to be able to attract FDI (see, for example, Lankes \& Stern, 1997; Sergi, 2003a) and liberalization measures have indeed been taken already in a number of the regional countries. In the field of fiscal policy, there is a broad consensus on its use as a means of attracting investors although to a much less extent that it has been in the past. In fact, these countries continue to benefit from significant labour cost advantages, even adjusted 
for labour productivity, as well as low corporate taxes and continuing tax competition (Kubicova, 2004; Sergi, 2005).

Some improvements in stability and economic freedom have been accomplished, while FDI has had positive effects in local subsidiaries and a further multiplier effect may be expected through supplier chains. Future positive spill over effects as regards domestic companies and branches and human capital, in addition to the transfer of technological expertise and the diffusion of up-to-date management techniques could prove important for socio-economic growth, in its broadest sense. The rise in labour productivity and the significantly increased export orientation of FDI subsidiaries makes all countries highly dependent on the situation in EU markets.

Nevertheless, instability, low intra-regional trade, low aggregate demand, trade and so on are the other side of the coin. Apart from Croatia (the last EU member, as of July 1, 2013), exports to the EU in the SEE rely on unskilled labour and low technology. For that reason, creating good medium-term prospects through regional integration (defined as a condition for the EU accession of the remaining SEE countries) is important (Sergi, 2003a). Thus, expanding regional cooperation, which so far has been strongly limited to specific areas and largely imposed by the international presence in the region, would further advance SEEEU relations. Of no less importance and urgency is the challenging task of fighting and making progress in such damaging areas as corruption, organised crime, human trafficking and illegal trading. Together, these factors are of decisive importance in attracting further foreign investment and generating substantial changes in economic growth. Critical to progress on these issues is the establishment of robust and sustainable patterns with regard to the rule of law. The EU's Stabilisation and Association Process provides helpful guidelines on the adoption of the relevant policies and strategies to strengthen the rule of law.

\section{CONCLUSION}

This paper has espoused the real social welfare difficulties among the south-east European countries. The Eurozone crisis and, in fact, the overall global economic downturn, have had noticeable negative effects on the already high unemployment rates of the region, and it had further contributed to social disparities between varying groups, be it gender or age-based.

The south-east European countries have to vigorously pursue economic and democratic governance reforms, strengthen the institutional setting, fight corruption, enhance competitiveness, and deepen regional cooperation. A functioning single economic space in the region, along with sustained EU integration and financial sector reform efforts, is a path to not only revive the weakened economies, but also set the stable parameters of a longer term strategic social and economic betterment. Thus, maintaining the focus on reform, cooperation, innovation and production is both a matter of grave urgency and long-term strategic priority.

The south-east European countries have been very diverse over the past decade and this has been reflected in their economic growth rates. The so-called 'latecomers'-following the example of those countries that experienced economic growth and foreign investment earlier-need to strengthen their competitiveness through a system which is much more oriented towards pro-business requirements. If there are grounds for foreign capital inflows to be released by the last 'round' of privatization, the region calls for much greater efforts designed for constructive end results. The underlying purpose remains that of becoming aware of the 'EU factor', greater regional co-operation in the advancement of industry clusters, and various incentives - all these factors being of equal worth to foreign investors.

Progressive and innovative pro-business oriented policies in the south-east Europe region should be designed to produce an economic environment which can respond successfully to rapid changes in an ultracompetitive business situation both regionally and internationally. To that end, and in keeping with the 
evolving European and international conditions, industrial policies must be structured in such a way as to provide the highest degree of flexibility and responsiveness for entrepreneurs. Additional policy decisions could be considered by countries of the region in their efforts to reduce unemployment and sustain development. Given the geographic location, a more pro-active approach could be envisaged so as to attracting investors from Asia and also to boost trade volumes outside the EU, depending on whether or not they are members of the EU.

This setting, of necessity, encompasses many important aspects, while industrial policy is included in the stability and attractiveness requirements for becoming a region of economic success, making the most of the very interesting geographical position it enjoys and construing a productive platform for goods and services to be exported to west and to east.

Even if signs of normalisation are clearly discernible in the economy of south-east European region as a whole, this cannot be said of the labour market. Active labour market policies, such as vocational training and educational programmes for workers, are needed. If policy reforms were essential to restore competitiveness, boost job creation and make it more inclusive, this would impose a burden of wide-ranging social consequences. Extensive consultations between the social partners are crucial to maintaining social cohesion while restoring overall competitiveness and engineering a successful and lasting economic recovery.

\section{REFERENCES}

Agency for Statistics of Bosnia and Herzegovina. (2011). Labour Force Survey: Final Results. November, Thematic Bulletin TB10, 2011.

Balaj, B. (2010). The Impact of the Global Economic Crisis. In J. Bugajski (Ed) Western Balkans Policy Review 2010. Washington, D.C.: Center for Strategic and International Studies.

Bartlett, W., \& Uvalić, M. (2013). Introduction' in W. Bartlett and M. Uvalić (Ed). The Social Consequences of the Global Economic Crisis in South East Europe. London: LSEE - Research on South East Europe.

Croatian Bureau of Statistics. (2012). Labour Force Survey. First Release, No. 9.2.7/1, 19 July 2012.

Dobbs, R., \& Madgavkar, A. (2012). Why the jobs problem is not going away. Retrieved from http://www.voxeu.org/article/why-jobs-problem-not-going-away

EBRD. (2002). Transition Report 2002: Agriculture and Rural Transition. London: EBRD.

EBRD. (2004). Transition Report 2002: Infrastructure. London: EBRD.

EBRD. (2016-2017). Transition Report 2016-2017: Transition for all: Equal opportunities in an unequal world. London: EBRD.

Eurostat. (2016). Enlargement countries - labour market statistics. Retrieved May 11, 2017 from http://ec.europa.eu/eurostat/statistics-explained/index.php/Enlargement countries labour market statistics.

Eurostat. (2017). Unemployment statistics. Retrieved August 2017 from http://ec.europa.eu/eurostat/statisticsexplained/index.php/Unemployment statistics \& 'Euro are unemployment at $9.1 \%$ ', http://ec.europa.eu/eurostat/documents/2995521/8194186/3-31082017-AP-EN.pdf/31c3bf62-0880-4da89cd4-471e60151f94.

Freeman, R. (2011). 10. New roles for unions and collective bargaining post the implosion of Wall Street capitalism. The Role of Collective Bargaining in the Global Economy: Negotiating for Social Justice, 254-276.

Freeman, R. (2012). Foreword: What Happened to Shared Prosperity and Full Employment and How to Get Them Back: A Seussian Perspective' in L.D. Appelbaum (Ed). Reconnecting to Work: Policies to Mitigate Long-Term Unemployment and Its Consequences Kalamazoo, MI: W.E. Upjohn Institute for Employment Research, pp. viixviii.

Galgóczi, B., \& Sergi, B. S. (2012). Social and economie trends in south-east Europe. SEER: Journal for Labour and Social Affairs in Eastern Europe, 51-60.

Institute for Regional and International Studies. (2010). The Western Balkans: Between the Economic Crisis and the European Perspective. Sofia: Balkan Trust for Democracy. 
International Labour Organization. (2010). Global Employment Trends. Geneva, January 2010.

International Labour Organization. (2011). Global Employment Trends for Youth: 2011 Update. Geneva, October 2011.

International Labour Organization. (2016). World Employment Social Outlook: Trends 2016. Geneva.

Kubicova, J. (2004). Tax competition in today's world'in BS Sergi and WT Bagatelas. The Slovak Economy and EU Membership, 205-231.

Lankes, H.P., \& Stern, N. (1997). Capital flows to Eastern Europe and the former Soviet Union. Working Paper 27 , London: EBRD.

Montenegro Statistical Office. (2012). Labour Force Survey 1st Quarter 2012, Release No. 159, 15 June 2012.

Ndulo, M. B., \& Duthie, R. (2009). The Role of Judicial Reform in Development and Transitional Justice' in: P.D. Greiff and R. Duthie (eds.). Transitional Justice and Development: Making Connections. Social Science Research Council: New York, pp. 250-281.

Qerimi, Q. (2002). South-east Europe's EU integration: Dreams and realities. South-East Europe Review for Labour and Social Affairs, 5(4), 43-56.

Qerimi, Q.R. (2005). Human values-based approach to development. Amartya Sen and Central Eastern Europe. In Bruno S. Sergi and William T. Bagatelas (Eds.) Ethical implications of post-communist transition economics and politics in Europe. Bratislava: Iura.

Qerimi, Q.R., \& Sergi, B.S. (2006). On the relevance of the EU as a means of spurring a socially-sustainable SouthEast Europe. South-East Europe Review for Labour and Social Affairs, 8(3), 111-120.

Roubini, N., \& Mihm, S. (2010). Crisis Economics: A Crash Course in the Future of Finance. London: Allen Lane.

Sergi, B. S. (2003). FDI and the Balkans: a regional investment agency and regional centred economic choices to shape this decade. South-East Europe Review for Labour and Social Affairs, 6(1/2), 7-16.

Sergi, B. S., \& Qerimi, Q. R. (2005). The European Union and its prospective enlargement to the south-east. SouthEast Europe Review for Labour and Social Affairs, 8(4), 15-32.

Sergi, B. S., \& Qerimi, Q. R. (2006). Business perspectives in Southeast Europe. Transition Studies Review, 13(3), 541555.

Sergi, B. S., \& Qerimi, Q. R. (2006). Upgrading the Balkans regional infrastructure. South-East Europe Review for Labour and Social Affairs, 9(1), 89-96.

Sergi, B.S. (1997). How to speed up growth and keep debts at bay. Transition Newsletter (World Bank), 8(6), 15-16.

Sergi, B.S. (2003b). Economic dynamics in transitional economies: the four-p governments, EU enlargement and the Brussels Consensus. New York: International Business Press.

Sergi, B.S. (2004). Understanding the EU factor: the Balkan region as recipient of FDI and industries. South-East Europe Review for Labour and Social Affairs, 7(4), 7-20.

Sergi, B.S. (2005). The Balkans jump on the tax rivalry bandwagon. South-East Europe Review for Labour and Social Affairs, $8(1), 7-18$.

Sergi, B.S. (2006). Central and peripheral regions in Europe: can tax competition attract foreign direct investment forever?. Washington, DC: American Consortium on European Union Studies (ACES), ACES Cases No. 2006.3.

Sergi, B.S., \& Qerimi, Q.R. (2007). Fighting corruption and organised crime as a means of socio-economic development in south-east Europe. South-East Europe Review for Labour and Social Affairs, 2, 81-94.

Sergi, B.S., \& Qerimi, Q.R. (2008). The political economy of Southeast Europe from 1990 to the present. New York and London: Continuum International Publishing Group.

Statistical Office of the Republic of Serbia. (2012). Labour Force Survey. First Release No. 181, 29 July 2012.

World Bank. (2017). Trends in Migration and Remittances. Retrieved April 2017 from http://www.worldbank.org/en/news/infographic/2017/04/21/trends-in-migration-and-remittances-2017. 